\title{
Entrepreneurial Career Intentions of Alumni: A Study in a Turkish Foundation University
}

\author{
A. Tuğba Karabulut ${ }^{1}$ \\ ${ }^{1}$ Faculty of Commercial Sciences, Istanbul Commerce University, Turkey \\ Correspondence: A. Tuğba Karabulut, Faculty of Commercial Sciences, Istanbul Commerce University, Istanbul, \\ Turkey. Tel: 90-444-0413. E-mail: tkarabulut@ticaret.edu.tr
}

Received: September 2, 2013

Accepted: December 14, 2013

Online Published: January 20, 2014

doi:10.5539/ijbm.v9n2p30

URL: http://dx.doi.org/10.5539/ijbm.v9n2p30

\begin{abstract}
The purpose of this study is to present the findings of an exploratory research which was applied on alumni of the Faculty of Commercial Sciences in a foundation University in Istanbul in Turkey in spring semester of 2013. This university was established in 2001 and had 1500 alumni of its faculty of commercial sciences. It was not possible to reach e-mails or contact information of 200 alumni. Thus, the questionnaire was sent to 1300 alumni via e-mail and 332 usable questionnaires were sent back. The response rate is $26 \%$. This study was conducted on 332 alumni of the faculty of commercial sciences of the foundation university in Istanbul. The frequency distribution analysis was applied to data. It is an exploratory research because it is trying to reveal the problem, the current situation and the ideas of aumni of this unversity. This paper gives an insight from a Turkish university about entrepreneurial intentions of their students and alumni and contributions to them.
\end{abstract}

Keywords: alumni, entrepeneur, career intention, university

\section{Introduction}

It is important to track their alumni for universities. If universities keep track of their alumni, they can provide statistics to their prospective students about their alumni's jobs and careers to market their programs. They can market graduate, Phd and certificate programs to their alumni. They can use their alumni for lobbying and providing donations. On the other hand, it is difficult to keep the track of their alumni for universities. They need to have a specialized office and officers to keep in touch with their alumni for a long time. They need to revise their contact information when it is changed. Actually, the most important way to keep track of alumni is to create loyalty and commitment to their universities while they are attending to their majors. If students are not happy with their majors, programs or universities, they won't want to keep in touch with their universities when they graduate.

Nowadays, entrepeneurial careers have become more important for universities, students and governments. Governments try to provide funds to support entrepreneurship to create job opportunities. They cooperate with universities to establish incubation centers, technoparks or consultancy to prospective entrepreneurs. Universities try to dynamize their programs by providing entrepreneurial approaches and touches. They add entrepreneurship courses and programs to their current programs to provide more comprehensive and modernized education to their students. Students prefer these programs to have better careers, more opportunies for better lifestyle. Entrepreneurship courses and programs provide a global mindset for entrepreneurs for global expansion of their enterprises to create more job opportunities, global networks and foreign currencies to the economy. The purpose of this study is to present the findings of the research which was applied on alumni of the Faculty of Commercial Sciences in a foundation University in Istanbul, Turkey. This research is in the field of entrepreneurial career intentions of alumni.

This paper aims to give an insight about entrepreneurial career intentions of alumni in eight sections. Literature review related to alumni career studies will be presented in the next section. Entrepreneurial career studies applied to university students and alumniwill be discussed in the third section. Effects of universities' offerings on entrepreneurial careers of their students will be explained in the fourth section. Research methodology, frequency distribution analysis, and research findings will be presented in the following chapters respectively. Limitations and conclusion will be stated in the last chapter. 


\section{Literature Review}

Universities need to provide funds to keep in touch with their alumni. They need to keep interests of alumni about their universities alive in the rest of their lives. They need to start making investments to their students by providing better services, courses, and academicians. They need to wake up belonging and commitment feelings of their students and initaite school spirits and culture to gain their students during their education and when they graduate. They need to lead careers of their students with career development and improvement counselers and services. They need to give importance to alumni clubs and organize consistent, frequent activities to harvest the benefits of alumni tracking. Business schools especially try more to lead their students to entrepreneurship and keep track of them during their careers.

Bakioğlu et al. (2011) havehighlighted the importance of alumni tracking system in their study. Phillips et al. (1994) have found out that business graduates considered opportunities for advancement, job security, fringe benefits, pay and training programs. Graduates focus on flexibility and advancement opportunities (Zedeck, 1977), good relationships with superiors (Chow \& Luk, 1996) and working conditions (Turban et al., 1993) to choose their jobs (Moy \& Lee, 2002).

King (2003) has explained the approach about changing career from employee's perspective. He has revealed career preferences and career self-management of graduates in several organizations in UK. He has showed that endorsement of graduates tonew careers is limited. Graduates want to develop employability in a traditional career. He has concluded that traditional career has considerable value for both employers and employees.

Dimitrios (2008) has examined how graduates'careers are managed in corporate Greece. He has found out career changes of graduates in businesses. He has revealed that graduates' career orientations affecttheir career strategies. Personal and organizational characteristics such as gender, age, work experience, field of specialization, economic sector and activity, firm size, and employment contract do not affect career strategies of graduates. On the other hand, the traditional career of internal promotability has motivated graduates and leaded them to consider human capital accumulation and networking strategies.

Cocchiara et al. (2010) have examined perceptions of alumni who have MBA and specialist master's degrees in US to determine the influence of their degree program experiences on their career success perceptions. They have found out that female graduates have less salary gain but higher hierarchical levels and job satisfaction than male graduates. Social capital and perceived discrimination affect career success of graduates on hierarchical level salary gain indirectly. Female graduates view their graduate program as less effective for advancing their careers than male graduates. They (2010) have concluded that companies should make their diversity management practices apparent because female and minority MBA graduates consider them essential for job search.

Gutteridge (1973) has analyzed factors related to career progress of alumni of graduate business school. Alumni who have previous full-time work experience progress faster in their careers. There is a negative relationship between company size and salaries. Alumni who change functional areas and employers earn higher salaries.

Lau and Pang (2000) have tried to figure out significance of developing career goals and adopting appropriate career strategies during first two years of employment after graduation in Hong Kong. They have found out that respondents use strategies of enhancing promotability and improving image with superiors more frequently than establishing external contacts during their early career. Developing career goals and plans and improving image with superiors are significantly and positively related to satisfaction with progression.

As it is observed, it is difficult to make a career choice for a new graduate. Universities need to provide necessary information and knowledge for various career alternatives for students and alumni by highlighting the importance and advantages of entrepreneurial careers. In the next section, entrepreneurial career studies conducted on university students will be discussed.

\section{Entrepreneurial Career Studies Applied to University Studentsand Alumni}

There are several entrepreneurial career studies applied to students in higher education institutions (HEIs). However, there are few studies conducted on alumni of universities and graduate schools. It is difficult to keep the track of an extensive database of their alumni for many HEIs. Strategies, studies and activities of alumni should be integrated to overall strategy of universities and graduate schools. They have to conduct these studies continously for their management information system, being a learning organization, and marketing, public relations and financing purposes.

Carter and Collinson (1999) have highlighted perceptions of alumni towards the provision of entrepreneurship education in HEIs. Unfortunately, few HEIs provide enterprise training to their alumni. Although alumni are 
interested to start their own businesses, generation of an idea and lack of experience and finance are main constraints to establish business. They have found out that HEIs should provide financial management and business communication skills education, and develop support networks to encourage entrepreneurial activities. HEI's formal training programmes canhelp to develop informal business networks among alumni. Start-up training programmes should target younger alumni and focus on idea generation, finance and experience. HEI's should provide education to encourage potential entrepreneurs and continue post-experience education for their alumni.

Nabi et al. (2010) have examined the graduate entrepreneurship process which explains how students become entrepreneurs when they graduate. They have developed a framework which explains person-environment dimensions of this transition. The entrepreneurial maturity of the student and the complexity of the business idea are main aspects of this transition.

Gaddam (2008) has believed that nurturing entrepreneurial culture is essential for business schools which focus on creating ventures and entrepreneurs. He has determined eight factors which affect entrepreneurial intentions of MBA students. Personality is the most important factor followed by locus of control, need for achievement, and self-efficacy which affect students' decisions to establish ventures. Culture affects entrepreneurial intentions of students significantly whereas perceived feasibility, perceived desirability, university environment, subjective norms, and market and finance conditions affect entrepreneurial intentions of students.

Choy et al. (2005) have conducted a research to identify potential entrepreneurs among business undergraduates in Malaysia. They have found out that subjective norm, attitude towards behavior and perceived behavioral control comprising Theory of Planned Behavior and gender and parents' occupation affect entrepreneurial career. They have concluded that quality entrepreneurs emerge by focusing these factors.

Kristiansen and Indarti (2004) have determined entrepreneurial intentions of Indonesian and Norwegian undergraduate students. They have found out that level of entrepreneurial intentions of Indonesian students is higher than Norwegian students. Lower social status and economic remuneration of entrepreneurs in Norway are assumed as causes of these findings.

Hsu et al. (2007) have analyzed trends in entrepreneurship among Massachusetts Institute of Technology (MIT) alumni since 1930s. They have found out that number of new ventures established by MIT alumni have increased over 70 years. They have added that the median age of first time entrepreneurs has declined from 40's to 30's from 1950s to 1990s. More male alumni have becomeentrepreneurs than female alumni. Alumni who are not U.S. citizens become entrepreneurs at usually higher rates than American alumni. Changes in external entrepreneurial and business environment affect new venture establishments.

Byers et al. (2000) have estimated the number of technology companies formed by Stanford graduates and faculty in the San Francisco Bay Area. They have found out that 9\% of all graduates and 22\% of technical graduates and science and technology faculty have formed high-tech companies. There are 1,900 companies which employ 138,000 people and provide $37 \%$ of local high-tech employment.

Davey et al. (2011) have identified differences between European and African students with regard to their entrepreneurial intentions, attitudes towards entrepreneurship, role models and entrepreneurial experience. They have conducted a research on freshman business students at universities in Finland, Germany, Ireland, and Portugal and three developing (Uganda and Kenya) and emerging (South Africa) African countries. They have found out that although motivators for employment/self-employment are similar across the samples, more students from developing/emerging countries intend to be entrepreneuers and have more positive attitudes than students in industrialised European countries. The type of role models used and the extent of entrepreneurial experiences varied between countries. They have extended their research on graduate entrepreneurship. They have compared entrepreneurship intentions, attitudes and experiences between developing/emerging and developed nations. They have made suggestions on how to foster an entrepreneurial spirit and assist new-venture creations for students.

Akyüz et al. (2009) have conducted a research on senior students of faculty of forestry in Turkey to determine their career choices and entrepreneurial abilities. They have found out that most of these senior students want to establish their own businesses. Having courage and risk taking ability are the main factors to be entrepreneurs.

\section{Effects of Universities' Offerings on Entrepreneurial Careers of Their Students}

There are several studies which aim to determine effects of universities' efforts on entrepreneurial career choices and achievements of students. Some universities provide entrepreneurship courses, writing and examining business plans of students, incubation centers, entrepreneurship club activities, financial and moral 
support to their students in undergraduate, graduate or post-graduate levels. HEIs need to conduct researches to determine which activities are more beneficial for students to be entrepreneurs as a career choice. If universities keep track of their alumni in the rest of their lives, they can get the advantage of their entrepreneur alumni and their new ventures for emerging case studies, providing mentoring, internships, networking and real life entrepreneurial experiences for their students. They can start lobbying, offer life long learning programs, incubation centers and value chain for their alumni.

Nabi et al. (2006) has found out that although there are several studies on the career choice to start new ventures in the form of intention models, there are not enough studies about circumstances, stories, contexts and complexities of graduates to establish start-ups. There are not enough researches about a transition from entrepreneurial intentions to start-ups in terms of career development and decision making processes. The nexus between training, support, intent and career choice to establish start-ups are not comprehensively examined.

Kuratko (2005) has stated that the entrepreneurship and new-venture creation education curriculum and programs have increased recently. He has focused on trends and challenges in entrepreneurship education in the 21 st century.

Collins et al. (2004) have explained the gap between entrepreneurial needs and aspirations of students and the entrepreneurship education in HEIs in UK. They have done a strategic review of how HEIs can meet entrepreneurial needs of students to support their future aspirations.

Pittaway and Cope (2007) have explored themes within entrepreneurship education. They have concluded that entrepreneurship education affect student intention and propensity. On the other hand, the effectof entrepreneurship education on graduate entrepreneurship and effectiveness of these entrepreneurs are not clear. They have added that there is no concensus on meaning of entrepreneurship or enterprise education in implementation.

Knight (1987) have conducted a study to 225 entrepreneur alumniof the Western Business School to find out the following factors: whether their family members are entrepreneurs, the type of company which they worked before, reasons to be entrepreneurs, effects of entrepreneurship courses on their career decisions, effects of mentors on them, types of their ventures, their sources of financing, and their educational background. They have found out that potential entrepreneurs can be encouraged by business school programs, entrepreneurship can be taught in business schools and new ventures of alumniemerge cases for entrepreneurial courses.

According to Kolvereid and Moen (1997), although entrepreneurship is widely taught in business schools and universities, there are few studies investigating effects of entrepreneurship education. Theyhave compared behaviours of entrepreneurship major and other major business graduates in a Norwegian business schoool. They have found out thatentrepreneurship major graduates are more likely to start new businesses and have stronger entrepreneurial intentions than other major graduates.

Franke and Lüthje (2004) have compared entrepreneurial intentions of students at Vienna University and University of Munich with the results of MIT. They have found distinct patterns of entrepreneurial spirit in these universities. They believe that the lower level of founding intentions among students in Munich and Vienna may be causeddue to their less distinctive entrepreneurship education.

Lange et al. (2011) have conducted a research on Babson College alumni who graduated between 1985 and 2009 to explore the influence of entrepreneurship education on intentions to become entrepreneurs and full-time entrepreneurs. They have found out that taking two or more core entrepreneurship courses affect students' intention to become entrepreneurs and their becoming actual entrepreneurs when they graduate and long afterward positively. On the other hand, writing a business plan also affects these significantly but it isless strong than taking two or more core courses.

Edwards and Muir (2005) have provided a case study of entrepreneurial learning in the university. They have highlighted the importance of entrepreneurship courses and university policy for entrepreneurial learning. They have concluded that students can be lack of support, resources and finance to be entrepreneurs and access to entrepreneurial learning. Undergraduate students who don't have work experience can not use funded support for learning. Formal and informal entrepreneurial learning are required in every level of university education. Entrepreneurship courses should continue undergraduate, graduate and postgraduate levels.

Fayolle (2000) has conducted a research in 25 French Business Schools. He has presented direct and indirect effects of entrepreneurship courses; objectives and means of these programs. He has presented a proposition to explain effects of entrepreneurship courses and underestimated factors such as the strategic positioning of these schools. 
Cooper et al. (2004) have explained that the traditional lecture-based teaching and learning are insufficient to encourage students to be entrepreneurs. Active learning, interactive techniques provide opportunities for students to experience entrepreneurship by working with entrepreneurs. Hunter Centre for Entrepreneurship of University of Strathclyde offers Venture Management programme in which students from different disciplines work with entrepreneurs on business development projects. They have evaluated pros and cons of this programme from students' and entrepreneurs'perspectives to shape its development and positioning of a new programme 'Implementing Entrepreneurship' inwhich each student works with an entrepreneur on a business development project for eight weeks.

Henry et al. (2005) state that although entrepreneurship education and training programmes increase, there is a little uniformity. They believe that some aspects of entrepreneurship can be taught. Educators and trainers need to determine goals of these programs to assess their outcomes accurately.

Universities need to focus on entrepreneurship education in undergraduate, graduate and post graduate levels to make a difference in their alumni's lives. They can cooperate with their entrepreneur alumni to feed and improve their entrepreneurship programs and activities. Nowadays, there are several universities known by their entrepreneurship programs and activities. They achieve and sustain competitive advantages among their competitors due to their entrepreneurial point of view.

\section{Research Methodology}

The purpose of this study is to present the findings of an exploratory research which was applied on alumni of the Faculty of Commercial Sciences in a foundation University in Istanbul in Turkey in spring semester of 2013. This university was established in 2001 and had 1500 alumni of its faculty of commercial sciences. It was not possible to reach e-mails or contact information of 200 alumni. Thus, the questionnaire was sent to 1300 alumni via e-mail and 332 usable questionnaires were sent back. The response rate is $26 \%$. This study was conducted on 332 alumni of the faculty of commercial sciences of the foundation university in Istanbul. The frequency distribution analysis was applied to data. It is an exploratory research because it is trying to reveal the problem, the current situation and the ideas of aumni of this unversity.

\section{Research Findings}

Table 1. Graduated degree program

\begin{tabular}{lll}
\hline & $\mathrm{n}$ & $\%$ \\
\hline Business Administration & 103 & 31.2 \\
International Trade & 87 & 26.3 \\
Banking and Finance & 66 & 20.0 \\
Tourism & 55 & 16.7 \\
International Relations & 19 & 5.8 \\
Total & 330 & 100.0 \\
\hline
\end{tabular}

$31.2 \%$ of respondents have Business Administration degree whereas $26.3 \%$ of them have International Trade degree.

Table 2. Graduation year

\begin{tabular}{lcc}
\hline & $\mathrm{n}$ & $\%$ \\
\hline 2004 & 2 & 0.6 \\
2005 & 7 & 2.1 \\
2006 & 19 & 5.7 \\
2007 & 32 & 9.7 \\
2008 & 46 & 13.9 \\
2009 & 64 & 19.4 \\
2010 & 57 & 17.2 \\
2011 & 59 & 17.8 \\
2012 & 45 & 13.6 \\
Total & 331 & 100.0 \\
\hline
\end{tabular}


$19.4 \%$ of respondents graduated in 2009 whereas $17.8 \%$ of them graduated in 2011.

Table 3. Age

\begin{tabular}{ccc}
\hline & $\mathrm{n}$ & $\%$ \\
\hline $21-25$ & 165 & 49.7 \\
$26-30$ & 156 & 47.0 \\
$31-35$ & 10 & 3.0 \\
Diğer & 1 & 0.3 \\
Total & 332 & 100.0 \\
\hline
\end{tabular}

Almost half (49.7\%) of respondents are 21-25 years old whereas $47.0 \%$ of them are $26-30$ years old.

Table 4. Gender

\begin{tabular}{ccc}
\hline & $\mathrm{n}$ & $\%$ \\
\hline Female & 159 & 47.9 \\
Male & 173 & 52.1 \\
Total & 332 & 100.0 \\
\hline
\end{tabular}

$52.1 \%$ of respondents are males whereas $47.9 \%$ of them are females.

Table 5. Birth order among sisters and brothers

\begin{tabular}{ccc}
\hline & $\mathrm{n}$ & $\%$ \\
\hline 1. & 176 & 53.2 \\
2. & 118 & 35.6 \\
3. & 27 & 8.2 \\
4. & 8 & 2.4 \\
Other & 2 & 0.6 \\
Total & 331 & 100.0 \\
\hline
\end{tabular}

Most of the respondents (53.2\%) are the first child of their families whereas $35.6 \%$ of them are the second child of their family.

Table 6. Entrepreneurship course taking in university

\begin{tabular}{ccc}
\hline & $\mathrm{n}$ & $\%$ \\
\hline Yes & 151 & 45.9 \\
No & 178 & 54.1 \\
Total & 229 & 100.0 \\
\hline
\end{tabular}

Only $45.9 \%$ of respondents took entrepreneurship course in university. However, $54.1 \%$ of them did not take entrepreneurship course in university

Table 7. If alumni took an entrepreneurship course, its leading alumni to entrepreneurship

\begin{tabular}{ccc}
\hline & $\mathrm{n}$ & $\%$ \\
\hline Yes & 71 & 34.0 \\
No & 138 & 66.0 \\
Total & 209 & 100.0 \\
\hline
\end{tabular}


Only $34 \%$ of respondents believe that entrepreneurship course which they took leaded them to entrepreneurship.

Table 8. Entrepreneurs in an alumni's family

\begin{tabular}{lcc}
\hline & $\mathrm{n}$ & $\%$ \\
\hline Mother & 38 & 11.4 \\
Father & 165 & 49.7 \\
Sister/Brother & 28 & 8.4 \\
Aunt/Uncle & 55 & 16.6 \\
Grandmother/Gran & 46 & \\
dfather & & 13.9 \\
Total & 332 & 100.0 \\
\hline
\end{tabular}

Almost half (49.7\%) of the respondents have entrepreneur fathers whereas $16.6 \%$ of them have entrepreneur aunt/uncle.

Table 9. Future career plan of an alumni

\begin{tabular}{lcc}
\hline & $\mathrm{n}$ & $\%$ \\
\hline Continue to the same job & 107 & 37.4 \\
Being an entrepreneur & 92 & 32.2 \\
Move to private sector company & 77 & 26.9 \\
Move to public sector company & 10 & 3.5 \\
Total & 286 & 100.0 \\
\hline
\end{tabular}

$32.2 \%$ of the alumni plan to be entrepreneurs in the future.

Table 10. Alumni's career planning since university

\begin{tabular}{ccc}
\hline & $\mathrm{n}$ & $\%$ \\
\hline Yes & 215 & 68.5 \\
No & 99 & 31.5 \\
Total & 314 & 100.0 \\
\hline
\end{tabular}

$68.5 \%$ of the alumni plan their careers whereas $31.5 \%$ of them don't plan their careers since university.

Table 11. Number of employees in alumni's enterprise besides him/her and his/her partners

\begin{tabular}{lcc}
\hline & $\mathrm{n}$ & $\%$ \\
\hline 0 & 4 & 11.1 \\
$1-9$ & 21 & 58.3 \\
$10-49$ & 8 & 22.2 \\
$50-249$ & 3 & 8.4 \\
Total & 36 & 100.0 \\
\hline
\end{tabular}

$58.3 \%$ of alumni have $1-9$ employees whereas $22.2 \%$ of them have $10-49$ employees in their enterprises. 
Table 12. Annual revenues of an enterprise

\begin{tabular}{lcc}
\hline & $\mathrm{n}$ & $\%$ \\
\hline Up to 1 milion TL & 20 & 55.5 \\
$1.01-25$ milion TL & 15 & 41.7 \\
More than 25.01 milion TL & 1 & 2.8 \\
Total & 36 & 100.0 \\
\hline
\end{tabular}

$55.5 \%$ of the alumni's enterprises have up to 1 million TL annual revenues whereas $41.7 \%$ of them have $1.01-25$ million TL annual revenues.

Table 13. Capital gathering method to establish his/her enterprise

\begin{tabular}{lcc}
\hline & $\mathrm{n}$ & $\%$ \\
\hline Bank credit & 11 & 31.4 \\
Family support & 14 & 40.0 \\
Partnership & 6 & 17.2 \\
Other & 4 & 11.4 \\
Total & 35 & 100.0 \\
\hline
\end{tabular}

$40.0 \%$ of the alumni used family resources whereas $31.4 \%$ of them used bank credit as capital gathering method to establish his/her enterprise.

Table 14. Stage of an enterprise

\begin{tabular}{lcc}
\hline & $\mathrm{n}$ & $\%$ \\
\hline Introduction & 12 & 33.3 \\
Growth & 22 & 61.1 \\
Intrapreneurship & 1 & 2.8 \\
Other & 1 & 2.8 \\
Total & 36 & 100.0 \\
\hline
\end{tabular}

$61.1 \%$ of the alumni's enterprises are in the growth stage whereas $33.3 \%$ of them are in introduction stage.

Activities which leaded an alumni to entrepreneurship

Table 15. Courses, presentations and training related to entrepreneurs

\begin{tabular}{lcc}
\hline & $\mathrm{n}$ & $\%$ \\
\hline Strongly Disagree & 8 & 21,6 \\
Disagree & 4 & 10,8 \\
Undecided & 4 & 10,8 \\
Agree & 9 & 24,4 \\
Strongly Agree & 12 & 32,4 \\
Total & 37 & 100,0 \\
\hline
\end{tabular}

$32.4 \%$ of alumni strongly agree and $24.4 \%$ of them agree that courses, presentations and training related to entrepreneurs leaded them to entrepreneurship. 
Table 16. Books, web sites, movies related to entrepreneurs

\begin{tabular}{lcc}
\hline & $\mathrm{n}$ & $\%$ \\
\hline Strongly Disagree & 6 & 16,2 \\
Disagree & 7 & 18,9 \\
Undecided & 4 & 10,8 \\
Agree & 7 & 18,9 \\
Strongly Agree & 13 & 35,2 \\
Total & 37 & 100,0 \\
\hline
\end{tabular}

$35.2 \%$ of alumni strongly agree and $18,9 \%$ of them agree that books, web sites, movies related to entrepreneurs leaded them to entrepreneurship.

Table 17. Field trips to new ventures and gathering information about them

\begin{tabular}{lcc}
\hline & $\mathrm{n}$ & $\%$ \\
\hline Strongly Disagree & 5 & 13.5 \\
Disagree & 5 & 13.5 \\
Undecided & 4 & 10.8 \\
Agree & 7 & 18.9 \\
Strongly Agree & 16 & 43.3 \\
Total & 37 & 100.0 \\
\hline
\end{tabular}

$43.3 \%$ of alumni strongly agree and $18.9 \%$ of them agree that field trips to new ventures and gathering information about them leaded them to entrepreneurship.

Table 18. Attending to panels inwhich entrepreneurs attended and meeting with them

\begin{tabular}{ccc}
\hline & $\mathrm{n}$ & $\%$ \\
\hline Strongly Disagree & 4 & 10.8 \\
Disagree & 5 & 13.5 \\
Undecided & 5 & 13.5 \\
Agree & 5 & 13.5 \\
Strongly Agree & 18 & 48.6 \\
Total & 37 & 100.0 \\
\hline
\end{tabular}

$48.6 \%$ of alumni strongly agree and $13.5 \%$ of them agree that attending to panels inwhich entrepreneurs attended and meeting with them leaded them to entrepreneurship.

Table 19. Meeting with angel investors and venture capital companies

\begin{tabular}{lcc}
\hline & $\mathrm{n}$ & $\%$ \\
\hline Strongly Disagree & 6 & 17.2 \\
Disagree & 4 & 11.4 \\
Undecided & 4 & 11.4 \\
Agree & 7 & 20.0 \\
Strongly Agree & 14 & 40.0 \\
Total & 35 & 100.0 \\
\hline
\end{tabular}

$40 \%$ of alumni strongly agree and $20 \%$ of them agree that meeting with angel investors and venture capital companies leaded them to entrepreneurship. 
Table 20. Writing and presenting business plans

\begin{tabular}{lcc}
\hline & $\mathrm{n}$ & $\%$ \\
\hline Strongly Disagree & 5 & 13.5 \\
Disagree & 8 & 21.6 \\
Undecided & 5 & 13.5 \\
Agree & 7 & 18.9 \\
Strongly Agree & 12 & 32.5 \\
Total & 37 & 100.0 \\
\hline
\end{tabular}

$32.5 \%$ of alumni strongly agree and $18.9 \%$ of them agree that writing and presenting business plansleaded them to entrepreneurship.

Table 21. Attending to entrepreneurship club activities

\begin{tabular}{lcc}
\hline & $\mathrm{n}$ & $\%$ \\
\hline Strongly Disagree & 14 & 37.8 \\
Disagree & 7 & 18.9 \\
Undecided & 7 & 18.9 \\
Agree & 4 & 10.8 \\
Strongly Agree & 5 & 13.5 \\
Total & 37 & 100.0 \\
\hline
\end{tabular}

$37.8 \%$ of alumni strongly disagree and $18.9 \%$ of themdisagree that attending to entrepreneurship club activitiesleaded them to entrepreneurship.

Table 22. Internship and work experience in new ventures

\begin{tabular}{lcc}
\hline & $\mathrm{n}$ & $\%$ \\
\hline Strongly Disagree & 10 & 27.1 \\
Disagree & 6 & 16.2 \\
Undecided & 5 & 13.5 \\
Agree & 8 & 21.6 \\
Strongly Agree & 8 & 21.6 \\
Total & 37 & 100.0 \\
\hline
\end{tabular}

$27.1 \%$ of alumni strongly disagree and $16.2 \%$ of them disagree that internship and work experience in new ventures leaded them to entrepreneurship.

Table 23. Role modeling of family members and their support

\begin{tabular}{lcc}
\hline & $\mathrm{n}$ & $\%$ \\
\hline Strongly Disagree & 6 & 16.2 \\
Disagree & 2 & 5.4 \\
Undecided & 4 & 10.8 \\
Agree & 2 & 5.4 \\
Strongly Agree & 23 & 62.2 \\
Total & 37 & 100.0 \\
\hline
\end{tabular}

$62.2 \%$ of alumni strongly agree and $5.4 \%$ of them agree that role modeling of family members and their supportleaded them to entrepreneurship. 
Table 24. Effect and support of other entrepreneurs

\begin{tabular}{lcc}
\hline & $\mathrm{n}$ & $\%$ \\
\hline Strongly Disagree & 5 & 13.5 \\
Disagree & 2 & 5.4 \\
Undecided & 3 & 8.1 \\
Agree & 5 & 13.5 \\
Strongly Agree & 22 & 59.5 \\
Total & 37 & 100.0 \\
\hline
\end{tabular}

$59.5 \%$ of alumni strongly agree and $13.5 \%$ of them agree that effect and support of other entrepreneurs leaded them to entrepreneurship.

Table 25. Support of friends

\begin{tabular}{lcc}
\hline & $\mathrm{n}$ & $\%$ \\
\hline Strongly Disagree & 5 & 13.5 \\
Disagree & 3 & 8.1 \\
Undecided & 7 & 18.9 \\
Agree & 7 & 18.9 \\
Strongly Agree & 15 & 40.6 \\
Total & 37 & 100.0 \\
\hline
\end{tabular}

$40,6 \%$ of alumni strongly agree and $18,9 \%$ of them agree that support of friends leaded them to entrepreneurship.

Talble 26. Support of teachers

\begin{tabular}{lcc}
\hline & $\mathrm{n}$ & $\%$ \\
\hline Strongly Disagree & 9 & 24.3 \\
Disagree & 3 & 8.1 \\
Undecided & 10 & 27.1 \\
Agree & 8 & 21.6 \\
Strongly Agree & 7 & 18.9 \\
Total & 37 & 100.0 \\
\hline
\end{tabular}

$18.9 \%$ of alumni strongly agree and $21.6 \%$ of themagree that support of teachers leaded them to entrepreneurship.

Table 27. Support of career consulting companies

\begin{tabular}{lcc}
\hline & $\mathrm{n}$ & $\%$ \\
\hline Strongly Disagree & 15 & 40.6 \\
Disagree & 3 & 8.1 \\
Undecided & 9 & 24.3 \\
Agree & 4 & 10.8 \\
Strongly Agree & 6 & 16.2 \\
Total & 37 & 100.0 \\
\hline
\end{tabular}

$40.6 \%$ of alumni strongly disagree and $8.1 \%$ of them disagree that support of career consulting companiesleaded them to entrepreneurship. 
Table 28. Work experience in a family business

\begin{tabular}{lcc}
\hline & $\mathrm{n}$ & $\%$ \\
\hline Strongly Disagree & 7 & 19.4 \\
Disagree & 4 & 11.1 \\
Undecided & 0 & 0.0 \\
Agree & 6 & 16.7 \\
Strongly Agree & 19 & 52.8 \\
Total & 36 & 100.0 \\
\hline
\end{tabular}

$52.8 \%$ of alumni strongly agree and $16.7 \%$ of themagree that work experience in a family businessleaded them to entrepreneurship.

Table 29. Government support for entrepreneurship

\begin{tabular}{lcc}
\hline & $\mathrm{n}$ & $\%$ \\
\hline Strongly Disagree & 13 & 36.1 \\
Disagree & 3 & 8.4 \\
Undecided & 8 & 22.2 \\
Agree & 4 & 11.1 \\
Strongly Agree & 8 & 22.2 \\
Total & 36 & 100.0 \\
\hline
\end{tabular}

$36.1 \%$ of alumni strongly disagree and $8.4 \%$ of them disagree that government support for entrepreneurship leaded them to entrepreneurship.

Most of the respondent alumni were graduated from Business Administration degree program, they were graduated in 2009. They are 21-25 years old, males, and first child of their families. They did not takeentrepreneurship courses. Most of the alumni who took entrepreneurship courses were not leaded to entrepreneurship due to them. Almost half of the respondent alumni have entrepreneur fathers whereas almost $1 / 3$ of respondent alumni plan to be entrepreneurs in the future. Most of the respondent alumni plan their careers since university. On the other hand, most of the entrepreneur alumni have 1-9 employees.Most of the entrepreneur alumni enterprises earn annual revenues up to 1 million TL and they are in growth stage. $40 \%$ of entrepreneur alumni used family resources to establish their enterprises.

Most of the entrepreneur alumni agree or strongly agree that the following leaded them to entrepreneurship:

-Courses, presentations, and training related to entrepreneurs;

-Books, web sites, and movies related to entrepreneurs;

-Field trips to new ventures and gathering information about them;

-Attending to panels inwhich entrepreneurs attended and meeting with them;

-Meeting with angel investors and venture capital companies;

-Writing and presenting business plans;

-Role modeling of family members and their support;

-Effect and support of other entrepreneurs;

-Support of friends;

-Work experience in a family business.

More entrepreneur alumni agree or strongly agree that support of their teachers leaded them to entrepreneurship. On the other hand, most of the entrepreneur alumni disagree or strongly disagree that attending to entrepreneurship club activities leaded them to entrepreneurship.

-More entrepreneur alumni disagree or strongly disagree that the following leaded them to entrepreneurship: 
-Internship and work experience in new ventures;

-Support of career consulting companies;

-Government support for entrepreneurship.

As a summary, entrepreneurial skills, knowledge and experise can be gained during education in HEIs. However, entrepreneurs have some of their characteristics when they were born. They are also affected from their family, friends and environmental factors. HEIs need to analyze effects of entrepreneurship prrograms and activities to complement entrepreneurial characteristics of their students and alumni to accelerate new venture creation process.

\section{Limitations and Conclusion}

As it is explained, alumni track keeping system is important for universities. They need to invest time and money to keep in thouch with their alumni. They need to include alumni focused strategies to their overall corporate strategies. It is believed that this research gives an insight from a Turkish university about its contributions to entrepreneurial intentions and expectations of their students and alumni. It can be concluded that universities need to design comprehensive entrepreneurship courses, programs and activities to explain the concepts of entrepreneur and entrepreneurship, and advantages of entrepreneurship as a career choice to their students and alumni. Universities need to provide chances to observe and simulate lives of entrepreneurs; meet, talk and work with them to encourage their students and alumni to be entrepreneurs. They need to lead their students and alumni for entrepreneurial careers to make contribution to the economy.

This research was conducted on alumni of Faculty of Commercial Sciences of a foundation university in Istanbul, Turkey. It is a new university which was established in 2001. It had 1500 alumni but 1300 were reached via e-mail. These can be considered as limitations of this study. The scope and sample size of this research can be extended in further studies to make a comparision with this study. Other researches can be conducted in other foundation and public universities to compare these two types of institutions.

\section{References}

Akyüz, K. C., Gedik, T., Aydın, A., Yıldırım, İ., \&Akyüz, İ. (2009). Orman fakülteleri son sınıf öğrencilerinin meslek tercihleri ve girişimcilik yetenekleri. Uluslararası Íktisadi ve İdari İncelemeler Dergisi, 1(3), 139-157.

Bakioğlu, A., Yüksel, M., Akdağ, B., \& Canel, A. N. (2011). Yükseköğretimde mezun izleme sistemi: Marmara üniversitesi atatürk eğitim fakültesi mezunları üzerine bir araştırma. Yükseköğretim Dergisi, 1(2), 65-79.

Byers, T., Keeley, R., Leone, A., Parker, G., \& Autio, E. (2000). The impact of a research university in silicon valley entrepreneurship of alumni and faculty. The Journal of Private Equity, 4(1), 7-15. http://dx.doi.org/10.3905/jpe.2000.319972

Carter, S., \& Collinson, E. (1999). Entrepreneurship education: Alumni perceptions of the role of higher education institutions. Journal of Small Business and Enterprise Development, 6(3), 229-239. http://dx.doi.org/10.1108/EUM0000000006679

Choy, C. S., Kuppusamy J., \& Jusoh, M. (2005). Entrepreneurial careers among business graduates: Matchmaking using theory of planned behavior. International Journal of Entrepreneurship, 9, 67-90.

Cocchiara, F. K., Kwesiga, E., Bell, M. P., \& Baruch, Y. (2010). Influences on perceived career success: Findings from US graduate business degree alumni. Career Development International, 15(1), 39-58. http://dx.doi.org/10.1108/13620431011020880

Collins, L., Hannon, P. D., \& Smith, A. (2004). Enacting entrepreneurial intent: The gaps between student needs and higher education capability. Education Training, 46(8/9), 454-463. http://dx.doi.org/10.1108/00400910410569579

Cooper, S., Bottomley, C., \& Gordon, J. (2004). Stepping out of the classroom and up the ladder of learning: An experiential learning approach to entrepreneurship education. Industry and Higher Education, 18(1), 11-22. http://dx.doi.org/10.5367/000000004773040924

Davey, T., Plewa, C., \& Struwig, M. (2011). Entrepreneurship perceptions and career intentions of international students. Education Training, 53(5), 335-352. http://dx.doi.org/10.1108/00400911111147677

Dimitrios, M. M. (2008). Graduates' career orientations and strategies in corporate greece. Personnel Review, 37(4), 393-411. http://dx.doi.org/10.1108/00483480810877570 
Edwards, L. J., \& Muir, E. J. (2005). Promoting entrepreneurship at the university of glamorgan through formal and informal learning. Journal of Small Business and Enterprise Development, 12(4), 613-626. http://dx.doi.org/10.1108/14626000510628261

Fayolle, A. (2000). Exploratory study to assess the effects ofentrepreneurship programs on french student entrepreneurial behaviors. Journal of Enterprising Culture, 8(2), 169-184. http://dx.doi.org/10.1142/S0218495800000103

Franke, N., \& Lüthje, C. (2004). Entrepreneurial intentions of business students-A benchmarking study. International Journal of Innovation Technology Management, 1(3), 269-288. http://dx.doi.org/10.1142/S0219877004000209

Gaddam, S. (2008). Identifying the relationshipbetween behavioral motivesand entrepreneurial intentions:An empirical studybased on the perceptions ofbusiness management students. The Icfaian Journal of Management Research, 7(5), 35-55.

Gutteridge, T. G. (1973). Predicting career success of graduate business school alumni. Academy of Management Journal, 16(1), 129-137. http://dx.doi.org/10.2307/255048

Henry, C., Hill, F., \& Leitch, C. (2005). Entrepreneurship education and training: Canentrepreneurship be taught? Part I. Education Training, 47(2), 98-111. http://dx.doi.org/10.1108/00400910510586524

Hsu, D. H., Roberts, E. B., \& Eesley, C. E. (2007). Entrepreneurs from technology-based universities: Evidence from MIT. Research Policy, 36, 768-788. http://dx.doi.org/10.1016/j.respol.2007.03.001

King, Z. (2003). New or tradional careers? A study of UK graduates' preferences. Human Resource Management Journal, 13(1), 5-26. http://dx.doi.org/10.1111/j.1748-8583.2003.tb00081.x

Knight, R. M. (1987). Can business schools produce entrepreneurs? An empirical study. Journal of Small Business \& Entrepreneurship, 5(1), 17-26. http://dx.doi.org/10.1080/08276331.1987.10600283

Kristiansen, S., \& Indarti, N. (2004). Entrepreneurial intention among indonesian and norwegian students. Journal of Enterprising Culture, 12(1), 55-78. http://dx.doi.org/10.1142/S021849580400004X

Kolvereid, L., \& Moen, Ø. (1997). Entrepreneurship among business graduates: Does a major in entrepreneurship make a difference? Journal of European Industrial Training, 21(4), 154-160. http://dx.doi.org/10.1108/03090599710171404

Kuratko, D. F. (2005). The emergence of entrepreneurship education: Development, trends, and challenges. $\begin{array}{llll}\text { Entrepreneurship Theory } & \text { and }\end{array}$ http://dx.doi.org/10.1111/j.1540-6520.2005.00099.x

Lange, J. E., Marram, E., Jawahar, A. S., Yong, W., \& Bygrave, W. (2011). Does an entrepreneurship education have lasting value? A study of careers of 4,000 alumni. Frontiers of Entrepreneurship Research, 31(6/2), 210-224.

Lau, A., \& Pang, M. (2000). Career strategies to strengthen graduate employees' employment position in the hong kong labour market. Education Training, 42(3), 135-149. http://dx.doi.org/10.1108/00400910010372689

Moy, J. W., \& Lee, S. M. (2002). The career choice of business graduates: SMEes or MNCs? Career Development International, 7(6), 339-347. http://dx.doi.org/10.1108/13620430210444367

Nabi, G., Holden, R., \& Walmsley, A. (2010). From student to entrepreneur: Towards a model of graduate entrepreneurialcareer-making. Journal of Education and Work, 23(5), 389-415. http://dx.doi.org/10.1080/13639080.2010.515968

Nabi, G., Holden, R., \& Walmsley, A. (2006). Graduate career-making and business start-up: A literature review. Education Training, 48(5), 373-385. http://dx.doi.org/10.1108/00400910610677072

Pittaway, L., \& Cope, J. (2007). Entrepreneurship education: A systematic review of the evidence. International Small Business Journal, 25(5), 479-510. http://dx.doi.org/10.1177/0266242607080656 


\section{Copyrights}

Copyright for this article is retained by the author(s), with first publication rights granted to the journal.

This is an open-access article distributed under the terms and conditions of the Creative Commons Attribution license (http://creativecommons.org/licenses/by/3.0/). 